Research Article

\title{
A comparative study of efficacy and safety of combination of indacaterol and tiotropium versus formoterol and budesonide in moderate to severe COPD
}

\author{
Manohar M. Bende ${ }^{1}$, Sujata Dudhgaonkar ${ }^{2}$, Raviraj S. Jagdhani ${ }^{2 *}$
}

\author{
${ }^{1}$ Department of Pharmacology, \\ GMC, Chandrapur, West \\ Bengal, India \\ ${ }^{2}$ Department of Pharmacology, \\ SVNGMC, Yavatmal, \\ Maharashtra, India
}

Received: 01 July 2016

Accepted: 05 August 2016

*Correspondence to:

Dr. Raviraj S. Jagdhani,

Email: rsjagdhani@gmail.com

Copyright: () the author(s), publisher and licensee Medip Academy. This is an openaccess article distributed under the terms of the Creative Commons Attribution NonCommercial License, which permits unrestricted noncommercial use, distribution, and reproduction in any medium, provided the original work is properly cited.

\begin{abstract}
Background: COPD patients suffer persistent airflow obstruction and exacerbation despite treatment with LABA and ICS. Presently LABA+LAMA is least tested combination hence we want to compare efficacy and safety of combination of indacaterol and tiotropium versus formoterol and budesonide in moderate to severe COPD.

Methods: This was an open labelled, parallel group trial involving 60 patients. of moderate to severe COPD having baseline postbronchodilator FEV $1 \geq 30 \%$ predicted and less than $80 \%$ predicted already on some kind of COPD treatment were included and, efficacy on lung function (FEV1) and safety in two groups, indacaterol+tiotropium once daily dpi versus formoterol+budesonide twice daily bd dpi were testedi24 hours postdose (trough) DPI in symptomatic patients of COPD of moderate to severe grade. Statistical analysis was done using repeated measures of ANOVA followed by Turkeys test. P value less than 0.05 were considered statistically significant.

Results: Patient with baseline/post bronchodilator FEV1 $\geq 30 \%$ predicted and less than $80 \%$ predicted were included. The mean age was $55 \pm 5$ years. At 4 weeks mean \pm SEM in peak FEV1 in indacaterol+tiotropium was $85.77 \pm 4.002$ and in formoterol+budesonide was $77.33 \pm 5.598$. At 12 weeks, mean \pm SEM in peak FEV1 in indacaterol+tiotropium was $112.30 \pm 4.69$ and formoterol+budesonide was $103 \pm 6.35$. At 24 weeks, mean \pm SEM in peak FEV1 in indacaterol+tiotropium $=\quad 125.3 \pm 5.18$ and formoterol+budesonide $=112.7 \pm 5.89$. Adverse events were less in indacaterol+tiotropium group. No serious adverse event occurred. Indacaterol+tiotropium once daily is efficacious and safe as compared to formoterol+budesonide twice daily with less exacerbation.

Conclusions: In patients having poorly controlled COPD despite background therapy (LABA, etophylline+theophylline, etc.) the introduction of indacaterol+tiotropium once daily compared to formoterol+budesonide twice daily DPI significantly improved the FEV1 by sustained bronchodilation, decreased exacerbation and is safe. Further studies are needed to assess quality of life and cost analysis.
\end{abstract}

Keywords: COPD, Indacaterol + Tiotropium, Formoterol + Budesonide, FEV 1

\section{INTRODUCTION}

COPD is global public health disease with progressive airway obstruction and accelerated decline in pulmonary function test (PFT) with exacerbation triggered by infection. $^{1}$ It occur in males who smoke and characteristically starts after the age of 40 years. The closure of small bronchi-bronchioles with loss of elasticity, alveolar destruction leading to bronchial fibrosis and emphysema. The Rescue treatment is always with SABA (short acting beta 2 agonists) however $\mathrm{FEV}_{1}$ increase after SABA is generally less than $12 \%$, short lasting and large part of obstruction is irreversible. The Spirometric functions $\left(\mathrm{FEV}_{1}\right.$, Vital capacity, FVC) decline over time. The goal of treatment is to prevent the progression, to relieve sign and symptoms, increase exercise tolerance, reduce exacerbation, increase quality of life, reduce side effects and mortality. ${ }^{1}$ 
LABA (long acting beta 2 agonists) like salmeterol and formoterol are well known treatments for COPD. They are used twice daily. The new LABAs like indacaterol, vilanterol, landeolol, olodaterol, bambuterol are used once daily which provide quick/fast and prolonged bronchodilation and increase compliance and also reduce release of mediators from mast cell. ${ }^{17}$ LAMA (long acting muscarinic antaginists) like tiotropium, aclidinium, glycopyrronium, umeclidinium have action on large bronchi while bronchodilator LABA acts on small peripheral bronchioles. ${ }^{17}$ Many studies tested combination/FDC of LABA and LAMA demonstrating improved and extended bronchodilation, decreased rescue medicine use and exacerbations. The airway inflammation in COPD is not very responsive to corticosteroids except in advanced COPD with frequent exacerbations. Hence benefit of formoterol+ICS combination is questionable. LABA+LAMA, are increasingly studied proving efficacy and safety. ${ }^{2}$ Present study was planned to further gather evidence on efficacy and safety of combination of newly introduced LABA (indacaterol $150 \mathrm{mcg}$ ) and LAMA (tiotropium $18 \mathrm{mcg}$ ) and compare it with formoterol $12 \mathrm{mcg}$ with ICS budesonide $200 \mathrm{mcg}^{7}$ Aim was to evaluate and compare the efficacy, safety and tolerability of indacaterol 150 $\mathrm{mcg}$ and tiotropium $18 \mathrm{mcg}$ with formoterol $12 \mathrm{mcg}$ and budesonide $200 \mathrm{mcg}$ administered separately by DPI in moderate to severe COPD cases for 24 weeks. Objectives was to evaluate post bronchodilator $\mathrm{FEV}_{1}$ on spirometry and to evaluate adverse drug reactions.

\section{METHODS}

This study was an open labelled, parallel group, prospective, interventional, comparative, randomised control trial. This study was carried out in pulmonary medicine OPD of a tertiary care hospital during the period from $1^{\text {st }}$ march 2014 to $28^{\text {th }}$ February 2016. Patients with 3 months history of cough with sputum and breathlessness, with spirometric PFT i.e. post bronchodilator FEV1/FVC $<0.7$ were screened. Total 60 patients fulfilling the inclusion and exclusion criteria were recruited for this study. They were divided into two groups, 30 patients in group I and 30 patients in group II.

Patients in group I received indacaterol $150 \mathrm{mcg}$ DPI once daily and tiotropium $18 \mathrm{mcg}$ DPI once daily administered separately, while those in group II received formoterol $12 \mathrm{mcg}$ DPI twice daily and budesonide 200mcg DPI twice daily administered separately. Drugs required for this study were purchased from local market.

\section{Selection criteria}

\section{Inclusion criteria}

1. Patients aged more than 40 years and less than 70 years of either sex with moderate to severe COPD classified by GOLD 2014 guidelines.
2. Post bronchodilator FEV1/FVC $<70 \%$.

3. Post bronchodilator FEV $1 \geq 30 \%$ predicted and $<80 \%$ predicted.

4. Post bronchodilation FEV1 reversibility less than $12 \%$.

\section{Exclusion criteria}

1. Known case of asthma.

2. Women of child bearing age.

3. Abnormal LFT, KFT, respiratory tracts.

4. COPD exacerbation in last 6 weeks.

5. Active pulmonary tuberculosis.

6. Terminally ill patients, Patients with HIV, malignancies.

7. Patients with cardiovascular comorbidity, glaucoma, benign hypertrophy of prostate, uncontrolled diabetes mellitus.

\section{Patients allergic to study medications.}

After the protocol approval by the institutional ethics committee informed consent in local language of the participants was obtained.

Patients with exertional dyspnoea, chronic cough were selected. Their detailed past history, family and personal history of tuberculosis, asthma, smoking, diabetes mellitus, hypertension and drug history was recorded. After general and local examination, baseline investigations for CBC, RBS, LFT, KFT, Sputum AFB, Chest X Ray (PA view), ECG, USG abdomen and pelvis was done. As per selection criteria pre and post bronchodilator pulmonary function tests was done. Patient with 24 hour post bronchodilator FEV1/FVC < $70 \%$ and FEV1 $\geq 30 \%$ predicted and less than $80 \%$ predicted were recruited. Most of the patients were on background therapy with SABA, anti-microbial agents, etophylline and theophylline, antihistaminic, cough suppressants. Patients were randomly allocated to group I or group II using online random table. Patients in both the group were given salbutamol rota caps in case of exacerbation as a rescue medication.

Follow up was done per week initially for 4 weeks, twice weekly from 4 weeks to 12 weeks and per 4 weeks from 12 weeks to 24 weeks. In each follow up signs and symptoms, post bronchodilator FEV1 and adverse drug reaction (ADR) and tolerability were recorded.

Results were expressed as percentage and mean \pm SEM. The differences in mean between the two groups were analysed by repeated measures of ANOVA followed by 
Turkeys multiple comparison. $\mathrm{P}$ value less than 0.05 were considered statistically significant. Graph pad prism version 6 was used for calculation.

\section{RESULTS}

Table 1: Baseline characteristics of the patients $(n=30)$ receiving $(\mathrm{I}+\mathrm{T}) \mathrm{OD}$ and $(\mathrm{F}+\mathrm{B}) \mathrm{BD}$.

\begin{tabular}{|lll|l|}
\hline Variables & & $\begin{array}{l}\text { Group I } \\
\text { No. of patients } \\
(\mathrm{n}=30)(\%)\end{array}$ & $\begin{array}{l}\text { Group II } \\
\text { No. of patients } \\
(\mathrm{n}=30)(\%)\end{array}$ \\
\hline Age in & $40-50$ & $10(33.3 \%)$ & $12(40 \%)$ \\
years & $50-70$ & $20(66.7 \%)$ & $18(60 \%)$ \\
\hline Gender & Men & $26(86.7 \%)$ & $22(73.3 \%)$ \\
\cline { 2 - 4 } & Women & $4(13.3 \%)$ & $8(26.7 \%)$ \\
\hline
\end{tabular}

Table 2: Symptom complaints in COPD patients.

\begin{tabular}{|lll|}
\hline Symptom & No. of patients $(\mathbf{n}=\mathbf{3 0})$ & $(\boldsymbol{\%})$ \\
\hline Cough & 30 & 200 \\
\hline Sputum & 30 & 200 \\
\hline Breathlessness & 34 & 68 \\
\hline Wheeze & 10 & 20 \\
\hline Tiredness on exercise & 3 & 6 \\
\hline Chest discomfort & 8 & 16 \\
\hline
\end{tabular}

Total 60 patients of COPD satisfying selected criteria were divided into two groups of 30 each randomly. Group I received indacaterol (I) $150 \mathrm{mcg}$ DPI once daily and tiotropium (T) $18 \mathrm{mcg}$ DPI once daily, while group II received formoterol $(\mathrm{F}) 12 \mathrm{mcg}$ DPI twice daily and budesonide (B) $200 \mathrm{mcg}$ DPI twice daily. Table 1 show the demographic characteristics.

Table 1 shows demographic profile of COPD patients which was comparable. In both group majority of patients were from 50-70 years. Mean age was $55 \pm 5$ years in group I and 53 \pm 2 years in group II. Amongst these $86.7 \%$ men were in group I and $73.3 \%$ men were in group II. Women patients were less $(13.3 \%$ in group I and $26.7 \%$ in group II) since smoking habits were less in indian women.

Table 2 shows commonest complaints were cough with sputum followed by breathlessness, wheeze, tiredness on exercise, chest discomfort. Table 3 shows difference in FEV1 improvement at 4 weeks.

Improvement in FEV1 at the end of 4 weeks in group I was 50 to $100 \mathrm{ml}$ in $73.3 \%$ COPD patients and was 101 to $150 \mathrm{ml}$ in $26.7 \%$ COPD patients while improvement in FEV1 at the end of 4 weeks in group II was 50 to $100 \mathrm{ml}$ in $83.3 \%$ COPD patients and was 101 to $150 \mathrm{ml}$ in $16.7 \%$
COPD patients. There was difference of only $10 \%$. P value was not significant. Table 4 shows difference in FEV1 improvement at 12 weeks.

Improvement in FEV1 at the end of 12 weeks was 50 to $100 \mathrm{ml}$ in $30 \%$ of COPD patients, was 101 to $150 \mathrm{ml}$ in $63.3 \%$ of COPD patients and 151 to $170 \mathrm{ml}$ in $6.7 \%$ COPD patients in group I. While improvement in FEV1 at the end of 12 weeks in group II was 50 to $100 \mathrm{ml}$ in $46.7 \%$ COPD patients, was 101 to $150 \mathrm{ml}$ in $50 \%$ COPD patients and 151 to $170 \mathrm{ml}$ in $3.3 \%$ COPD patients. There was a difference of $16.7 \%, 13.3 \%$ and $3.4 \%$ respectively. $\mathrm{P}$ value was significant $(<0.05)$. Table 5 shows difference in FEV1 improvement at 24 weeks.

Table 3: Improvement in FEV1 $(\mathrm{ml})$ at 4 weeks in COPD patients $(n=30)$ receiving $(I+T)$ OD and $(F+B)$ BD.

\begin{tabular}{|llllll|}
\hline $\begin{array}{l}\text { FEV1 } \\
(\mathrm{ml})\end{array}$ & $\begin{array}{l}\text { Group I } \\
\begin{array}{l}\text { No. of } \\
\text { patients } \\
(\mathrm{n}=30)\end{array}\end{array}$ & $\begin{array}{l}\text { Group II } \\
\text { No. of } \\
\text { patients } \\
(\mathrm{n}=30)\end{array}$ & $\begin{array}{l}\text { P } \\
\text { value }\end{array}$ \\
\hline $\begin{array}{l}50 \text { to } \\
100 \mathrm{ml}\end{array}$ & 22 & 73.3 & 25 & 83.3 & NS \\
\hline $\begin{array}{l}101 \mathrm{to} \\
150 \mathrm{ml}\end{array}$ & 8 & 26.7 & 5 & 16.7 & NS \\
\hline
\end{tabular}

Table 4: Improvement in FEV1 (ml) at 12 weeks in COPD patients $(n=30)$ receiving $(I+T) O D$ and $(F+B)$

BD.

\begin{tabular}{|llllll|}
\hline $\begin{array}{l}\text { FEV1 } \\
(\mathrm{ml})\end{array}$ & $\begin{array}{l}\text { Group I } \\
\text { No. of } \\
\text { patients } \\
(\mathrm{n}=30)\end{array}$ & $\begin{array}{l}\text { Group II } \\
\text { No. of } \\
\text { patients } \\
(\mathrm{n}=30)\end{array}$ & $\%$ & $\begin{array}{l}\text { P } \\
\text { value }\end{array}$ \\
\hline $\begin{array}{l}50 \text { to } \\
100 \mathrm{ml}\end{array}$ & 9 & 30 & 14 & 46.7 & $<0.05$ \\
\hline $\begin{array}{l}101 \mathrm{to} \\
150 \mathrm{ml}\end{array}$ & 19 & 63.3 & 15 & 50 & $<0.05$ \\
\hline $\begin{array}{l}151 \mathrm{to} \\
170 \mathrm{ml}\end{array}$ & 2 & 6.7 & 1 & 3.3 & $<0.05$ \\
\hline
\end{tabular}

Improvement in FEV1 at the end of 24 weeks in group I was 50 to $100 \mathrm{ml}$ in $20 \%$ COPD patients, was 101 to $150 \mathrm{ml}$ in $63.3 \%$ COPD patients and 151 to $170 \mathrm{ml}$ in $16.7 \%$ COPD patients while in group II the improvement in FEV1 at the end of 24 weeks was 50 to $100 \mathrm{ml}$ in $46.7 \%$ COPD patients, was 101 to $150 \mathrm{ml}$ in $43.3 \%$ COPD patients and 151 to $170 \mathrm{ml}$ in $10 \%$ COPD patients. There was a difference of $26.7 \%, 20 \%$ and $6.7 \%$ respectively. $\mathrm{P}$ value was significant $(<0.05)$. Table 6 and Figure 1 shows difference in FEV1 improvement at $4,12,24$ weeks. 
Table 5: Improvement in FEV1 (ml) at 24 weeks in COPD patients $(\mathrm{n}=30)$ receiving $(\mathrm{I}+\mathrm{T}) \mathrm{OD}$ and $(\mathrm{F}+\mathrm{B}) \mathrm{BD}$.

\begin{tabular}{|llllll|}
\hline & FEV1 $(\mathrm{ml})$ & Group I & Group II & P value \\
\cline { 2 - 5 } & No. of patients $(\mathrm{n}=30)$ & $\%$ & $\begin{array}{l}\text { No. of patients } \\
(\mathrm{n}=30)\end{array}$ & $\%$ & \\
\hline 50 to $100 \mathrm{ml}$ & 6 & 20 & 14 & 46.7 & $<0.05$ \\
\hline 101 to $150 \mathrm{ml}$ & 19 & 63.3 & 13 & 43.3 & $<0.05$ \\
\hline 151 to $170 \mathrm{ml}$ & 5 & 16.7 & 3 & 10 & $<0.05$ \\
\hline
\end{tabular}

Table 6: Difference in improvement in FEV1 $(\mathrm{ml})$ at 4 weeks, 12 weeks and 24 weeks in COPD patients $(\mathrm{n}=30)$ receiving $(\mathrm{I}+\mathrm{T}) \mathrm{OD}$ and $(\mathrm{F}+\mathrm{B}) \mathrm{BD}$.

\begin{tabular}{|c|c|c|c|c|}
\hline Weeks & Group & FEV1 $(m \pm S E M)$ & $P$ value & $95 \% \mathrm{CI}$ \\
\hline \multirow[t]{2}{*}{4 weeks } & I & $85.77 \pm 4.002$ & \multirow[t]{2}{*}{$<0.001$} & 77.48 to 93.85 \\
\hline & II & $77.33 \pm 5.6$ & & 61.88 to 84.78 \\
\hline \multirow[t]{2}{*}{12 weeks } & I & $112.3 \pm 4.7$ & \multirow[t]{2}{*}{$<0.001$} & 102.7 to 121.9 \\
\hline & II & $103.0 \pm 6.36$ & & 89.98 to 116.0 \\
\hline \multirow[t]{2}{*}{24 weeks } & I & $125.3 \pm 5.18$ & \multirow[t]{2}{*}{$<0.001$} & 114.7 to 135.9 \\
\hline & II & $112.7 \pm 5.89$ & & 200.6 to 124.7 \\
\hline
\end{tabular}

There was statistically significant (CI) improvement in FEV1 $85.77 \pm 4.002$ (77.48 to 93.85$)$ in group I at 4weeks and at 12 weeks $112.3 \pm 4.7$ (102.7 to 121.9$)$ and at 24 weeks $125.3 \pm 5.18$ (114.7 to 135.9 ).

Table 7 shows ADR. Both groups tolerated these study drugs well. No serious adverse drug event reported in both the group. The ADR are shown in table 7. Adverse effects were comparable in two groups. Cough was reported in $16.6 \%$ patients $(10 \%$ in group I and $6.7 \%$ in group II), hoarseness of voice reported in $6.7 \%$ patients (group II), tremors in $10 \%$ patients (group II), dryness of mouth in $10 \%$ patients $(6.7 \%$ in group $I$ and $3.3 \%$ in group II), palpitation in $10 \%$ patients $(6.7 \%$ in group I and $3.3 \%$ in group II), Bad taste in $6.7 \%$ patients $(3.3 \%$ in group I and $3.3 \%$ in group II), headache in $6.7 \%$ patients (group II), sore throat in $3.3 \%$ patient (group II) and other in $6.7 \%$ patients $(3.3 \%$ in each group), side effects under others included nausea, diarrhoea, irritability, etc.

Table 8 shows duration of COPD illness. In group I the COPD duration was less than 2 years in $53.3 \%$ patients while in group II it was $46.7 \%$ patients. While it was 2 to 5 years in $30 \%$ patients in group I and $33.3 \%$ in group II patients. Duration was more than 5 years in $16.7 \%$ patients in group I and $20 \%$ in group II.

Table 7: ADR reported in COPD patients $(n=30)$ receiving (I+T) OD and $(\mathrm{F}+\mathrm{B}) \mathrm{BD}$ over 24 weeks.

\begin{tabular}{|lllll|}
\hline ADR & $\begin{array}{l}\text { Group I } \\
\text { No. of } \\
\text { patients } \\
(\mathrm{n}=30)\end{array}$ & $\begin{array}{l}\text { Group II } \\
\text { No. of } \\
\text { patients } \\
(\mathrm{n}=30)\end{array}$ & $\%$ \\
\hline $\begin{array}{l}\text { Cough on } \\
\text { inhalation }\end{array}$ & 3 & 10 & 2 & 6.66 \\
\hline $\begin{array}{l}\text { Hoarseness of } \\
\text { voice }\end{array}$ & 0 & 0 & 2 & 6.66 \\
\hline Tremors & 0 & 0 & 3 & 10 \\
\hline $\begin{array}{l}\text { Dryness of } \\
\text { mouth }\end{array}$ & 2 & 6.66 & 1 & 3.33 \\
\hline Palpitations & 2 & 6.66 & 1 & 3.33 \\
\hline Bad taste & 1 & 3.33 & 1 & 3.33 \\
\hline Headache & 0 & 0 & 2 & 6.66 \\
\hline Sore throat & 0 & 0 & 1 & 3.33 \\
\hline Others & 1 & 3.33 & 1 & 3.33 \\
\hline
\end{tabular}

Table 8: Duration of COPD in patients $(n=30)$ receiving $(I+T)$ OD and $(F+B) B D$.

\begin{tabular}{|lllll|}
\hline Duration & Group I & & Group II & \\
& No. of patients $(\mathrm{n}=30)$ & $\%$ & No. of patients $(\mathrm{n}=30)$ & 4 \\
\hline 0 to 2 years & 16 & 53.3 & 14 & 46.7 \\
\hline 2 to 5 years & 9 & 30 & 10 & 33.3 \\
\hline More than 5 years & 5 & 16.7 & 6 & 20 \\
\hline
\end{tabular}




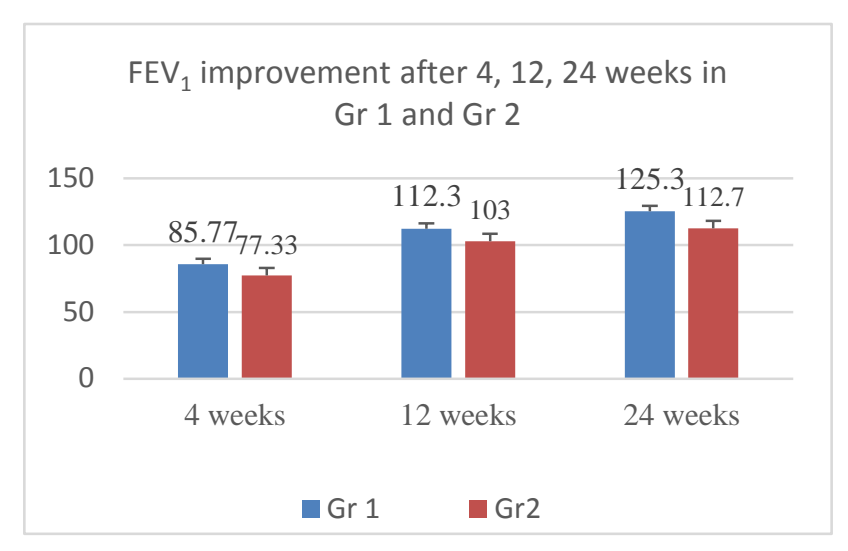

Figure 1: FEV1 improvement after 4, 12, 24 weeks in group 1 and group 2.

\section{DISCUSSION}

In this study both combinations indacaterol and tiotropium once daily DPI and formoterol and budesonide twice daily DPI were efficacious, safe, and well tolerated in moderate to severe COPD over 24 weeks however indacaterol and tiotropium once daily DPI was more efficacious and safe. ${ }^{2,9}$ Two parallel group of 30 patient each of both gender with mean age of $55 \pm 5$ years with postbronchodilator $\mathrm{FEV}_{1} \geq 30 \%$ predicted and less than $80 \%$ predicted were included in this study.

The improvement in $\mathrm{FEV}_{1}$ seen in both groups but higher value were observed in indacaterol and tiotropium at 12 and 24 weeks.

The indacaterol and tiotropium OD DPI 24 hour post dose (trough) at the end of 4 week was tested first. The $\mathrm{FEV}_{1}$ improved to $50-200 \mathrm{ml}$ from baseline in $73.3 \%$ patients but was less than formoterol and budesonide BD DPI $(83.3 \%)$. The $\mathrm{FEV}_{1}$ was $101-150 \mathrm{ml}$ in $26.7 \%$ patients which was more than formoterol and budesonide BD DPI $(16.7 \%)$. ( $\mathrm{I}+\mathrm{T}=\mathrm{M} \pm \mathrm{SEM}=85.77 \pm 4.012$, $95 \%$ CI $77.48-93.85, \mathrm{p}>0.05)$ results were not significant implying that both combinations are equally efficacious over 4 weeks use $(\mathrm{F}+\mathrm{B}=\mathrm{M} \pm \mathrm{SEM}=77.33 \pm$ $5.6,95 \%$ CI $61.88-84.78, \mathrm{p}>0.05 \%)$.

The indacaterol + tiotropium OD DPI 24 hour post dose (trough) at the end of 12 weeks showed the FEV1 improvement of $50-200 \mathrm{ml}$ in $30 \%$ patients, of $101-150 \mathrm{ml}$ in $63.3 \%$ patients and of $151-170 \mathrm{ml}$ in $6.7 \%$ patients $(\mathrm{M} \pm \mathrm{SEM}=112.30 \pm 4.690,95 \%$ CI 102.7 - 121.9, $\mathrm{p}<$ $0.05 \%$ ) while in formoterol and budesonide BD DPI the values were of $50-200 \mathrm{ml}$ in $46.7 \%$ patients, $101-150 \mathrm{ml}$ in $50 \%$ patients and $151-170 \mathrm{ml}$ in $3.4 \%$ patients. $\mathrm{P}$ value was significant implying that $\mathrm{I}+\mathrm{T}$ was significantly more efficacious than $\mathrm{F}+\mathrm{B}(\mathrm{M} \pm \mathrm{SEM}=103 \pm 6.4,95 \% \mathrm{CI}$ 89.98-116.0, $\mathrm{P}<0.05 \%)$.

The indacaterol and tiotropium OD DPI 24 hour post dose at the end of 24 weeks showed FEV1 improvement of $50-200 \mathrm{ml}$ in $20 \%$ patients, $101-150 \mathrm{ml}$ in $63.3 \%$ patients and $151-170 \mathrm{ml}$ in $16.7 \%$ patients. $(\mathrm{M} \pm \mathrm{SEM}=$ $125.3 \pm 5.18,95 \%$ CI 114.7-135.9, $\mathrm{p}<0.05 \%$ ) while in F+B BD DPI the FEV1 improvements were $50-200 \mathrm{ml}$ in $46.7 \%, 101-151 \mathrm{ml}$ in $43.3 \%$ patients, $151-170 \mathrm{ml}$ in $10 \%$ patients. $\mathrm{P}$ value was statistically significant implying that I+T OD DPI was more efficacious than formoterol and budesonide BD DPI. $(\mathrm{M} \pm \mathrm{SEM}=112.7 \pm 5.9,95 \% \mathrm{CI}$ 200.6-124.7, $\mathrm{P}<0.05 \%)$.

The 50-200 $\mathrm{ml} \mathrm{FEV}_{1}$ achievements were greater in formoterol and budesonide BD DPI throughout the testing period of 24 weeks while achievements of 151$170 \mathrm{ml}$ of $\mathrm{FEV}_{1}$ were more in indacaterol and tiotropium OD DPI group.

Bronchodilators which increase $\mathrm{FEV}_{1}$ are the mainstay of therapy. Use of LABA OD/BD resulted in improved clinical outcome and compliance. According to GOLD guidelines LABA are mainstay of treatment of COPD. Combination of indacaterol $150 \mathrm{mcg}+$ tiotropium $18 \mathrm{mcg}$ OD DPI improves bronchodilatation by different mechanisms, increased efficacy, reduce dose, raise compliance and reduce ADR. Preferentially LABA act on smaller bronchioles while LAMA act on bigger bronchi.

Formoterol + budesonide $\mathrm{BD}$ is a combination of LABA + ICS (inhalational corticosteroid budesonide) is available as FDC or separate preparations providing long term bronchodilation by formoterol and antiinflammatory action by budesonide. ${ }^{10}$ Adverse effects are low in both as tiotropium and budesonide have low systemic bioavailability. ${ }^{5}$

Outcome of this study showed improved $\mathrm{FEV}_{1}$ lung functions with both the treatment but efficacy was more with indacaterol + tiotropium OD DPI compared to formoterol + budesonide BD DPI. These observations are in agreement with other studies. ${ }^{16}$

INDORSE and INLIGHT trials tested dose, safety and efficacy of indacaterol $150 \mathrm{mcg}$, formoterol $12 \mathrm{mcg}$, tiotropium 18 mcg over 26 weeks. ${ }^{3,4}$ Indacaterol achieved more than $170 \mathrm{ml}$ of $\mathrm{FEV}_{1}$ over 52 weeks and also reduced exacerbations. INLIGHT study done on indacaterol $150 \mathrm{mcg}$ showed more efficacy vs placebo on large population achieving $\mathrm{FEV}_{1}$ of $130 \mathrm{ml}$ over 12 weeks. Indacaterol reduce rescue medications and improved health status. INLIGHT study tested indacaterol OD vs salmeterol for 26 weeks caused increase $\mathrm{FEV}_{1}$ up to $170 \mathrm{ml}$ plus less rescue medication required. The study by COPE et al compared indacaterol 150 vs FDC formoterol + budesonide, salmeterol + fluticasone, indacaterol was more efficacious. ${ }^{5,13}$

In our study indacaterol + tiotropium achieved $\mathrm{FEV}_{1}$ of $170 \mathrm{ml}$ after $12-24$ weeks in $23.4 \%$ patients and in formoterol + budesonide group in $13.3 \%$ patients. ${ }^{10}$ Dahl et al used indacaterol $150 \mathrm{mcg}$ and formoterol $12 \mathrm{mcg}$ for 1 year in COPD patient found indacaterol more efficacious. ${ }^{6}$ Also MEHLER et al. ${ }^{7,8}$ showed that 
indacaterol and tiotropium $18 \mathrm{mcg}$ was more efficaceous with mild ADR. Kerwin et al. ${ }^{8}$

Overall ADR noticed over a period of 24 weeks were less and comparable in both groups. No SAE were reported. In indacaterol + tiotropium cough on inhalation (3), dryness of mouth (2) were the most reported side effects, palpitation (2), bad taste (1), other (1) were reported voluntarily. In formeterol+budesonide group cough on dry powder inhalation in (2) hoarseness of voice (2), tremors (3), dryness of mouth (1), palpitation (1) taste alteration (1), headache (1), sore throat (1), excess sweating (1). These were in agreement with other trials, were similar to placebo and comparable to other LABA..$^{3,8,11,14,15}$ Our study had some limitations.

Sample size was small, to detect small but potentially significant difference. Our is a open label trial, duration of study was short, COPD cases due to other causes were not included, also had less women sample. The Indacaterol + tiotropium is costly hence compliance may change due to cost. We have not compared FDC. Side effects studied were self-reported, objective assessment and lab abnormalities were not assessed. We did not follow patients hence efficacy safety beyond 24 weeks remained untested. Further studies are needed over extended period and using large sample size, testing cost effectiveness.

\section{CONCLUSION}

In conclusion, the present study observed indacaterol and tiotropium once daily DPI given together separately showed statistically significant $\mathrm{FEV}_{1}$ improvement and clinical improvement versus formoterol and budesonide. ADR also were low except cough and hoarseness of voice in both groups. Both combinations are efficacious and well tolerated, however indacaterol and tiotropium was found more efficacious. Thus indacaterol and tiotropium once daily in moderate to severe COPD provide superior bronchodilation in comparison to formoterol and budesonide twice daily. More studies are needed to test long term safety.

Funding: No funding sources Conflict of interest: None declared

Ethical approval: The study was approved by the Institutional Ethics Committee

\section{REFERENCES}

1. Decramer M, Agusti AG, Bourbeau J, Celli BR, Chen R, Criner $\mathrm{G}$ et al. Global strategy for diagnosis, management and prevention of COPD. 2016. Available at: http://www.goldcopd.org/uploads/users/files/GOLD_ Report_2016.pdf.

2. Nobuyuki H. LAMA/LABA vs ICS/LABA in the treatment of COPD in Japan based on the disease phenotypes. Int $\mathrm{J}$ Chron Obstruct Pulmon Dis. 2015;10:1093-102.

3. Chapman KR, Rennard SI, Dogra A, Owen R, Lassen C, Kramar B; INDORSE Study Investigators. Long term efficacy and safety of indacaterol, a long acting beta2 agonist, in subjects with COPD: a randomized, placebo-controlled study. Chest. 2011;140(1):68-75.

4. Kornmann O, Dahl R, Centanni S, Dogra A, Owen R, Lassen C, Kramer B. INLIGHT-2 study investigators. Once daily indacaterol versus twice-daily salmeterol for COPD: a placebo-controlled comparison. Eur Respir J. 2011;37(2):273-9.

5. Cope S, Capkun-Niggli G, Gale R, Lassen C, Owen R, Ouwens MJ, Bergman G, Jansen JP. Efficacy of once-daily indacaterol relative to alternative bronchodilators in COPD: a patient-level mixed treatment comparison. Value health. 2012;15(3):52433.

6. Dahl R, Chung KF, Buhl R, Magnussen H, Nonikov V, Jack D, Bleasdale P, Owen R, Higgins M, Kramer B. INVOLVE study investigators. Efficacy of a new once-daily long acting inhaled beta2-agonist indacaterol versus twice daily formoterol in COPD. Thorax. 2010;65(6):473-9.

7. Mahler DA, D'Urzo A, Bateman ED, Ozkan SA, White T, Peckitt C, Lassen C, Kramer B; INTRUST1 and INTRUST-2 study investigators. Concurrent use of indacaterol plus tiotropium in patients with COPD provides superior bronchodilation compared with tiotropium alone. a randomized, double blind comparison. Thorax. 2012;67(9):781-8.

8. Kerwin EM, Gotfried MH, Lawrence D, Lassen C, Kramer B. Effiacy and tolerability of indacaterol $75 \mathrm{mcg}$ once daily in patients aged $\geq$ than 40 years with COPD: results from 2 double-blind, placebocontrolled 12-week studies. Clin Ther. 2011;33(12):1974-84.

9. Abebaw MY, Martin JC, Nicola AH. Ten years of tiotropium: clinical impact and patient perspectives. Int J Chron Obstruct Pulmon Dis. 2013;8:117-25.

10. Matsushima S, Inui N, Yasui H, Kono M, Nakamura Y, Toyoshima M, Shirai T, Suda T. Indacaterol an tiotropium combination therapy in patients with COPD. Pulm Pharmacol Ther. 2015;30:11-5.

11. Jutta B, Kai MB: LABA in the management of COPD: focus on indacaterol. Int J Chron Obstruct Pulmon Dis. 2011;6:237-43.

12. Worth H, Chung KF, Felser JM, Hu H, Rueeqq P. Cardio and cerebrovascular safety of indacaterol vs formoterol, salmeterol, tiotropium and placebo in COPD. Respir Med. 2011;105(4):571-9.

13. Bateman ED, Ferguson GT, Barnes N. Dual bronchodilation with QVA149 versus single bronchodilator therapy: the SHINE study. Eur Respir J. 2013;42(6):1484-94.

14. Mahler DA, D’Urzo A, Bateman ED. Concurrent use of indacaterol plus tiotropium in patients with COPD provides superior bronchodilation compared with tiotropium alone: a randomised, double-blind comparison. Thorax. 2012;67:781-8. 
15. Decramer $\mathrm{M}$, Dahl R, Kornmann O, Korn $\mathrm{S}$, Lawrence D, McBryan D. Effects of long acting bronchodilators in COPD patients according to COPD severity and ICS use. Respiratory Medicine. 2013;107(2):223-32.

16. Mahler DA, Kerstjens AM, Donohue JF, Buhl R, Lawrence D, Altman P. Indacaterol vs Tiotropium in COPD patients classified as GOLD A and GOLD B.
2015.

Available

at:

http://dx.doi.org/10.1016/j.rmed.2015.05.012.

17. Katzung BG, Trevor AJ. Basic and Clinical Pharmacology. $13^{\text {th }}$ ed. ISBN-13: 978-0071825054.

Cite this article as: Bende MM, Dudhgaonkar S, Jagdhani RS. A comparative study of efficacy and safety of combination of indacaterol and tiotropium versus formoterol and budesonide in moderate to severe COPD. Int J Basic Clin Pharmacol 2016;5:2006-12. 